Abstracta Iranicacta Iranica

Revue bibliographique pour le domaine irano-aryen

Volume 32-33 | 2013

Comptes rendus des publications de 2009-2010

\title{
J. Elayi, A. G. Elayi. Nouveau trésor de Byblos d'après les archives de H. Seyrig (TLXXXIII)
}

\section{Astrid Nunn}

\section{(2) OpenEdition}

1 Journals

Édition électronique

URL : http://journals.openedition.org/abstractairanica/40246

DOI : 10.4000/abstractairanica.40246

ISSN : 1961-960X

\section{Éditeur :}

CNRS (UMR 7528 Mondes iraniens et indiens), Éditions de l'IFRI

\section{Édition imprimée}

Date de publication : 1 décembre 2013

ISSN : 0240-8910

\section{Référence électronique}

Astrid Nunn, « J. Elayi, A. G. Elayi. Nouveau trésor de Byblos d'après les archives de H. Seyrig (TLXXXIII)», Abstracta Iranica [En ligne], Volume 32-33 | 2013, document 57, mis en ligne le 01 juillet 2016, consulté le 26 septembre 2020. URL : http://journals.openedition.org/abstractairanica/40246 ; DOI : https:// doi.org/10.4000/abstractairanica.40246

Ce document a été généré automatiquement le 26 septembre 2020.

Tous droits réservés 


\section{J. Elayi, A. G. Elayi. Nouveau trésor de Byblos d'après les archives de H. Seyrig (TLXXXIII)}

\section{Astrid Nunn}

\section{RÉFÉRENCE}

J. Elayi, A. G. Elayi. « Nouveau trésor de Byblos d'après les archives de H. Seyrig (TLXXXIII) ». Trans. 38, 2009, p. 65-76.

1 Les AA., spécialistes de numismatique phénicienne, ont retravaillé sur un trésor du Musée de Beyrouth qu'Henri Seyrig avait déjà étudié dans les années 60. Ils se sont cette fois-ci penchés sur des archives déposées au Cabinet des médailles de la Bibliothèque de France. Le catalogue des monnaies rassemblées par H. Seyrig n'avait pas été illustré mais les descriptions sont assez exactes pour pouvoir tirer profit d'une nouvelle étude.

2 L'origine du trésor est inconnue. Il se compose au total de 54 monnaies en argent, dont 24 sicles et 7 divisionnaires de Byblos, ainsi que de 23 autres monnaies de Tyr, Sidon, Athènes, Kition et de Lycie. Le trésor remonte à environ 435, son enfouissement à 425 av. J.-C. Son importance réside dans le fait qu'il permet de dater les séries de Byblos en chronologie absolue. 


\section{AUTEURS}

\section{ASTRID NUNN}

Université de Munich 